\title{
SUSTAINABLE DEVELOPMENT OF THE HOUSING ESTATES THROUGH THE EXAMPLE OF RADOGOSZCZ-EAST IN LÓDŹ
}

\begin{abstract}
In case of progressive degradation of the natural environment, more emphasis is put on the actions which would minimize the humanity's negative influence on the environment. An attempt to answer ecological issues is the concept of sustainable development which assumes permanent development of humanity but not at the expense of the natural environment.

Nowadays environmentally friendly solutions are frequently used in modern residential buildings. However major challenge is to adapt existing buildings to contemporary requirements. Especially demanding problems are large housing estates built in socialism which dominated the structure of Polish cities before the propagation of sustainable development principles.

Research problem of this article is a question: can blocks of flats develop in a sustainable way? In order to answer this question a research based on a methodology by Beata Komar ${ }^{1}$ through the example of Radogoszcz-East - housing complex located in Łódź was conducted. The object of this study was appraisal of particular aspects of sustainable development (ecological, economic, social and cultural) with reference to block of flats. Additional materials to this analysis were questionnaires for inhabitants about the quality of life in this area.
\end{abstract}

Keywords: Sustainable development, block of flats, large housing estates, urban audit, degradation.

\section{Sustainable development}

Rapid civilization development which occurred in the second half of the $19^{\text {th }}$ century and Earth's population increase had major impact on the idea of sustainable development. In those days the human's effort was focused on constant economic growth regardless the negative impact on the natural environment which progressed considerably.
${ }^{1}$ B. Komar (2014). 
Up until the 60 's of the $20^{\text {th }}$ century none had suspected how serious the consequences of unreasonable environmental policy would be. The international community was alarmed at $23^{\text {rd }}$ United Nations session of the General Assembly in 1967 where it was indicated that lack of immediate action pose a threat to life on Earth.

Since that time many significant documents were published. One of the most crucial was the Report of the Secretary-General of the United Nations Sithu U Thanta (1969), titled: The problems of human environment because it initialized global discussion about the environmental crisis.

The definition of sustainable development which emerged in "Our common future" named „Brundtland Report” in 1987 is considered as the most popular and imaginative:

Humanity has the ability to make development sustainable to ensure that it meets the needs of the present without compromising the ability of future generations to meet their own needs ${ }^{2}$.

The emphasis was laid not only on the responsibility towards all humanity but also towards future generations which would live in the environment left after present mankind.

As a consequence of international tendency for environmental protection, the concept of sustainable development was written into the Constitution of the Republic of Poland ${ }^{3}$. However more detailed legal definition can be found in the Environmental Protection Law ${ }^{4}$.

To conclude sustainable development implies economic growth together with the protection of environmental quality, each reinforcing the other. The essence of this form of development is a stable relationship between human activities and the natural world, which does not diminish the prospects for future generations to enjoy a quality of life at least as good as nowadays (Fig. 1).

\section{Blocks of flats}

Large housing estates built in the era of socialism accomplished the aim they were built for - considerable number of average standard flats was delivered promptly. Nowadays it is hard to imagine the landscape of Polish cities without extensive block of flats complexes. Despite the criticism of housing estates, the numerous advantages of these residential buildings must be emphasised. First and foremost,

${ }^{2}$ Report of the World Commission on Environment and Development: Our Common Future, „Sustainable development knowledge platform”, 1987: 16, www.sustainabledevelopment.un.org/content/documents/5987our-common-future.pdf (accessed on: 02.06.2016).

${ }^{3}$ Constitution of the Republic of Poland from $2^{\text {nd }}$ April 1997 (Dz.U., 1997, nr 78, poz. 483, art. 5).

${ }^{4}$ Environmental Protection Law from $27^{\text {th }}$ April 2001 (Dz.U., 2017, poz. 519, art. 3). 


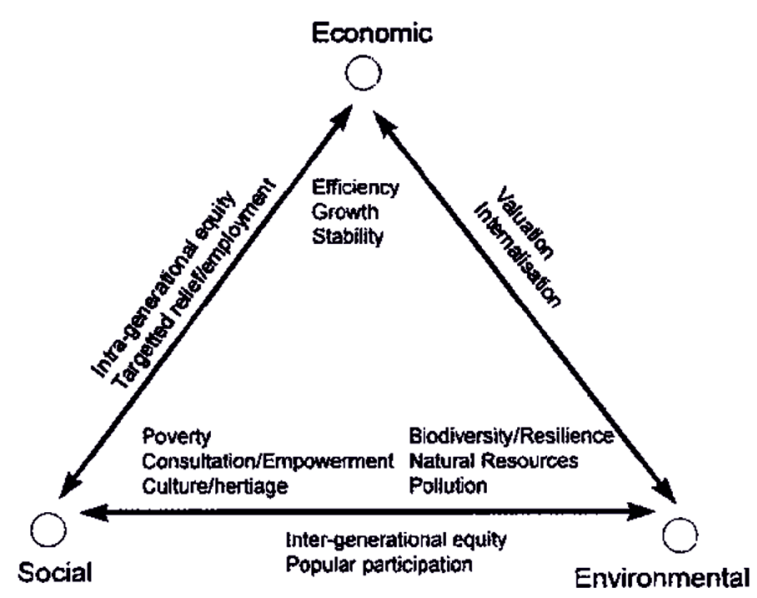

Fig. 1. Sustainable development triangle

Source: http://fao.org

usually blocks of flats are located near city centres and are very well linked to other city parts by public transport. However the distance is far enough for inhabitants to feel the relief from big city bustle. Another convenience is good accessibility to basic services and well developed social and technical infrastructure. Nowadays block of flats' residents can satisfy most of their needs inside the estate thanks to various shops, supermarkets, playgrounds and green areas.

Despite all the profits, large housing estates are still considered pejoratively. This kind of residential buildings has many drawbacks which resulted from those days government's faults as well as economic insufficiency of that time.

First housing estates built from giant slab in Łódź emerged in the late 50's of $20^{\text {th }}$ century. According to Ewa Szafrańska Łódź's big residential complexes divide into three categories related to its built date because of different normative provisions which had an influence on the flats' area and social or demographic structure of residents. Radogoszcz belongs to the youngest group (80's and 90's). Flats in this category are characterized by largest area, the lowest average age of inhabitants, biggest percentage of employed people and smallest number of one-person household (Szafrańska 2010).

\section{Urban audit of space in Radogoszcz-East estate}

According to recommendations from Athens Charter and Leipzig Charter on Sustainable European Cities, the idea of sustainable development should be the core to elaborate quality requirements for blocks of flats (Komar 2014: 90). To investigate if the estate is developing in a sustainable way it is necessary to conduct an urban audit. Beata Komar has devised research tool which facilitates all kinds 
of urban studies. In her methodology quality requirements are divided in three groups of factors: ecological, economic, social and cultural, what corresponds with the sustainable development triangle (Table 1). Some of the factors may be assigned to more than one group. It means that sustainable development can be achieved only if all three spheres are integrated. Beata Komar presented her tool through the example of three estates in Katowice in comparison with Grünau estate in Leipzig. Her methodology proved to be very universal and can be used to assess space in other complexes after slight modifications.

Table 1. Quality requirements to housing estates according to sustainable development principles

\begin{tabular}{|c|c|c|c|}
\hline \multirow[b]{2}{*}{ Criterion } & \multicolumn{3}{|c|}{ Sustainable development triangle } \\
\hline & Ecology & Economy & $\begin{array}{c}\text { Society and } \\
\text { culture }\end{array}$ \\
\hline 1. Public transport, cycling, walking & $\mathrm{X}$ & & \\
\hline 2. Waste separation & $\mathrm{X}$ & & \\
\hline 3. Energy efficiency & $\mathrm{X}$ & $\mathrm{X}$ & \\
\hline 4. Parking lots & $\mathrm{X}$ & & $\mathrm{X}$ \\
\hline 5. Green areas & $\mathrm{X}$ & & $\mathrm{X}$ \\
\hline 6. Water management & $\mathrm{X}$ & $\mathrm{X}$ & \\
\hline 7. Safety and design out crime & & & $\mathrm{X}$ \\
\hline 8. Universal design & & & $\mathrm{X}$ \\
\hline 9. Urban layout & & & $\mathrm{X}$ \\
\hline 10. Recreation areas & & & $\mathrm{X}$ \\
\hline 11. Aesthetic quality of space & & & $\mathrm{X}$ \\
\hline 12. Social infrastructure & & & $\mathrm{X}$ \\
\hline 13. Social participation & & & $\mathrm{X}$ \\
\hline
\end{tabular}

Source: own elaboration based on B. Komar (2014: 94)

According to Agenda 21 - the action programme adopted on the Earth Summit in 1992, the most crucial requirement towards ecological issues is to enhance the natural environment, instead of damaging it. In case when some loss in inevitable, the consequences must be minimized and compensated ${ }^{5}$. In author's opinion water management should be added to ecological requirements because clean water

${ }^{5}$ Agenda 21, United Nations Conference on Environment and Development, Rio de Janeiro, 3-14 June 1992, based on: B. Komar (2014: 94). 
is extremely precious and its rational usage affects the condition of the natural environment.

When it comes to economic aspects of sustainable development, all kinds of actions reducing costs should be considered, e.g. thermal modernizations or water saving solutions. Moreover every investment which leads to improvement in life quality is valuable because although in does not bring financial benefits directly, in the future it may increase investment attractiveness of the estate.

Social and cultural requirements are all of the operations which improve inhabitants' life quality, their safety and level of content (Komar 2014: 105). The author assumes that one of the most important factors is social participation which allows achieving the most effective solutions, reinforcing the residents' integration and creating an attachment to the local community.

The construction of Radogoszcz-East began in 1979. The estate is located in the north of Łódź, near the border with city Zgierz. It belongs to Łódź-Bałuty district. Radogoszcz estate is divided into three parts. The East part, managed by the cooperative of people (SMRW) is the subject of this dissertation. The structure of the estate is based on system of yards which differ from each other with shape and size. Thanks to that the inhabitants of the yard have some privacy. It also helps to create a bound between the people and their living place. In Radogoszcz-East there are several green areas and recreation objects like playing fields, outdoor gyms and playgrounds. Shops and other services are mostly located in the ground floors of buildings around Plac Słoneczny which has a function of local market. Most of residents' needs can be satisfied inside the estate what is especially crucial for elderly people. The biggest issue of the estate is the lack of parking places. Unfortunately there are no modern ecological solutions like rainwater harvesting or solar panels. Radogoszcz-East has satisfactory connection with city centre (about $6 \mathrm{~km}$ away) as well as by public transport and by car. It is only $2,6 \mathrm{~km}$ away from enormous forest called Las Łagiewnicki (Fig. 2).

\section{The result of the urban audit for Radogoszcz-East in Lódź}

Every criterion was graded in the scale from $1-5$ or $1-3$. The final outcome has been divided into three groups of results:

- positive (green colour): in scale 1-5 grades 4 and 5, in scale 1-3 grade 3;

- warning (yellow colour): in scale $1-5$ grade 3 , in scale $1-3$ grade 2 ;

- negative (red colour): in scale 1-5 grades 1-2, in scale 1-3 grade 1 (Table 2).

Most of the criteria were assessed positively in Radogoszcz-East. Notwithstanding the only aspect graded $5 / 5$ was green areas. It means that there are still some improvements that can be done. The worst aspects are parking lots and water management. 


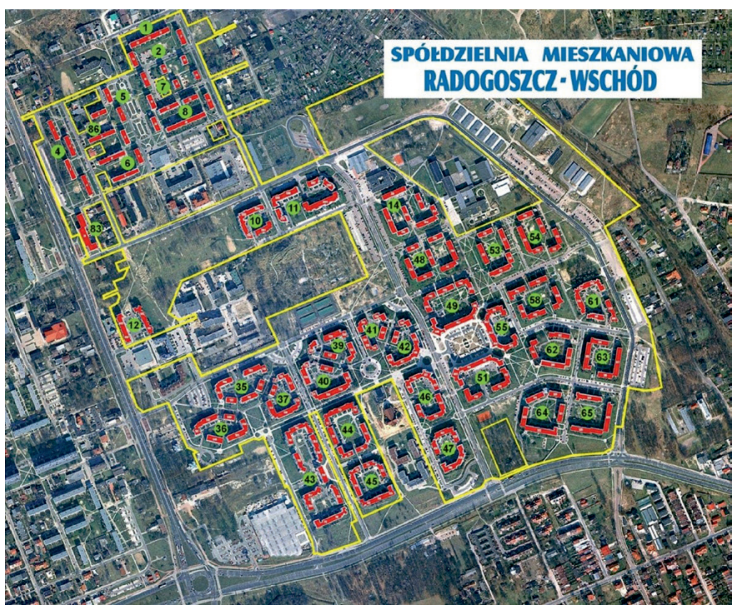

Fig. 2. Radogoszcz-East Estate in Łódź

Source: www.smrw.lodz.pl

Table 2. The result of the urban audit for Radogoszcz-East in Łódź

\begin{tabular}{lc}
\hline \multicolumn{1}{c}{ Criterion } & Grade \\
\hline \multicolumn{1}{c}{ Ecology } \\
\hline Public transport, cycling, walking & $4 / 5$ \\
\hline Waste seperation & $2 / 3$ \\
\hline Parking lots & $1 / 3$ \\
\hline Green areas & $5 / 5$ \\
\hline Water management & $0 / 3$ \\
\hline \multicolumn{1}{c}{ Society and Culture } \\
\hline Energy efficiency \\
\hline \multicolumn{2}{|c}{} \\
\hline Safety and design out crime & $4 / 5$ \\
\hline Universal design & $2 / 3$ \\
\hline Urban layout & $2 / 3$ \\
\hline Parking lots & $4 / 5$ \\
\hline Green areas & $1 / 3$ \\
\hline Recreation areas & $4 / 5$ \\
\hline Social infrastructure & $4 / 5$ \\
\hline Aesthetic quality of space & $4 / 5$ \\
\hline Social participation & $4 / 5$ \\
\hline Sum & $2 / 3$ \\
\hline
\end{tabular}

Source: own elaboration 
To conclude, even blocks of flats can be adapted to nowadays quality requirements and be a competition for modern residential housing. Some of the housing estates in Poland are 50 years old and require immediate actions in order to avoid irreversible devastation. The result of this research confirms that elaborating revitalization projects should be done according to the sustainable development principles. Moreover the methodology devised by Beata Komar after a slight modifications appear to be flexible enough to be used in different locations and estates.

\section{Bibliography}

Agenda 21, United Nations Conference on Environment and Development, Rio de Jane-iro, 3-14 June 1992, based on: B. Komar (2014: 94).

Constitution of the Republic of Poland from $2^{\text {nd }}$ April 1997 (Dz.U., 1997, nr 78, poz. 483, art. 5).

Environmental Protection Law from 27th April 2001 (Dz.U., 2017, poz. 519, art. 3).

Komar B., 2014, Wspótczesna jakość spótdzielczej przestrzeni osiedlowej w świetle zasad rozwoju zrównoważonego na wybranych przykładach, Wydawnictwo Politechniki Śląskiej, Gliwice.

Report of the World Commission on Environment and Development: Our Common Future, „Sustainable development knowledge platform”, 1987, www.sustainabledevelopment. un.org/content/documents/5987our-common-future.pdf (accessed on: 02.06.2016).

Szafrańska E., 2010, Wielkie osiedla mieszkaniowe w okresie transformacji - próba diagnozy i kierunki przemian na przykładzie Łodzi, [w]: Jażdżewska I. (ed.), Osiedla blokowe $w$ strukturze przestrzennej miast, Wydawnictwo Uniwersytetu Łódzkiego, Łódź.

\section{ROZWÓJ ZRÓWNOWAŻONY OSIEDLI BLOKOWYCH NA PRZYKLADZIE OSIEDLA RADOGOSZCZ-WSCHÓD W LODZI}

Zarys treści: W świetle postępującej degradacji środowiska naturalnego, coraz większy nacisk kładzie się na działania mające na celu zminimalizowanie negatywnego wpływu człowieka na środowisko. Próbą odpowiedzi na problemy ekologiczne jest koncepcja zrównoważonego rozwoju, która zakłada zapewnienie trwałego rozwoju ludzkości, ale nie kosztem środowiska. W nowoczesnym budownictwie mieszkaniowym coraz bardziej powszechne są rozwiązania proekologiczne. Ogromnym wyzwaniem jest natomiast dostosowanie budynków już istniejących do dzisiejszych wymagań. Szczególnie trudnymi przypadkami są osiedla blokowe, masowo budowane w epoce socjalizmu, które zdominowały struktury polskich miast. Budowane były w czasach, gdy ochrona środowiska była zepchnięta na najdalszy możliwy plan. Zatem pytanie brzmi: czy osiedla blokowe mogą się rozwijać w sposób zrównoważony? Podmiotem badań zostało osiedle blokowe Radogoszcz-Wschód w Łodzi. W celu rozwiązania problemu badawczego przeprowadzono audyt urbanistyczny przestrzeni osiedla według metodologii opracowanej przez Beatę Komar. 
W pierwszym kroku wyznaczono wymagania jakościowe wobec osiedli blokowych w świetle zasad zrównoważonego rozwoju, z podziałem na czynniki ekologiczne, ekonomiczne i społeczno-kulturowe. Następnie zinwentaryzowano zasoby osiedla Radogoszcz-Wschód i dokonano oceny poszczególnych kryteriów. W efekcie zostały wskazane mocne strony przestrzeni osiedla oraz obszary problemowe, które nie spełniają wymagań zrównoważonego rozwoju. Wyniki badań wskazują jednak, że pomimo złej sławy, osiedla blokowe po pewnych modyfikacjach mogą rozwijać się w sposób zrównoważony. Metodologia oparta na koncepcji zrównoważonego rozwoju jest uniwersalna i pomaga w sposób kompleksowy ocenić stan przestrzeni osiedlowych i wskazać wytyczne do strategii rewitalizacji blokowisk.

Słowa kluczowe: Rozwój zrównoważony, osiedla blokowe, blokowiska, audyt urbanistyczny, degradacja.

Karolina Rychta, Eng. Spatial Economy College Łódź University of Technology e-mail: rychta.karolina@gmail.com 